\title{
INFLUENZA A/H10 VIRUSES OF WILD BIRDS, MAMMALS AND HUMANS
}

\author{
Zhumatov K.Kh., Kydyrmanov A.I. \\ Scientific Production Center Microbiology and Virology \\ 10, Bogenbay batyr str., Almaty,050010, Kazakhstan. \\ Lizaveta4ka@list.ru
}

\begin{abstract}
Emerging infectious diseases pose a serious threat to wildlife, domestic animals, and public health. Of the more than 335 human infectious diseases that have emerged over the past six decades, influenza is one of the most common infection, causing up to 650,000 deaths per year. In addition to the annual seasonal influenza $A$, the emergence of its new, pandemic, and highly pathogenic variant is even more dangerous. This review describes the classification of influenza pathogens, their structural features, and sources of isolation. The latest published data on the structure, ecology, phylogenesis and pathogenicity of influenza $A$ subtype $\mathrm{H10}$ viruses from various host species are summarized. It is noted that the avifauna is not the only possible reservoir for $\mathrm{H10}$ influenza viruses; avian H10N8 infected dogs in China and mink in Scandinavia, and H10N7 caused widespread mortality of seals in the Baltic Sea in 2014. The first three human cases of avian influenza A H10N8 were reported in 2013-2014 in China, one of which lead to mortality. Information is provided on the genetic variability and evolution of influenza A subtype $\mathrm{H10}$ strains circulating in avifaunal, mammalian, and human populations. Influenza A subtype $\mathrm{H10}$ virus is actively evolving by exchange of genetic information. The potential epidemiological hazard of influenza $A$ virus (H10N8) is as a causative agent of a pandemic, and the need to control its circulation in populations of birds, mammals and among the people is emphasized.

Key words: influenza virus A, subtype H10, avian, genome, variability, phylogenesis.
\end{abstract}

\section{INTRODUCTION}

The number of newly emerging infectious diseases in the world is growing, and they pose a serious threat to wildlife, domestic animals and public health [1]. Of more than 335 human diseases that have emerged over the past six decades, influenza is one of the most common infections causing up to 650,000 deaths per year, according to new estimates by the US Centers for Disease Control and Prevention (CDC) of the United States and WHO. [2]. In addition to the annual seasonal influenza A, the emergence of its new, pandemic, highly virulent variant, against which immunity is virtually nonexistent, is even more dangerous.

The global and uncontrolled spread of influenza A viruses is primarily due to their unique variability, which is based on both point mutations characteristic of RNAcontaining viruses and recombination and reassortment of genes. Their genome consists of eight fragments encoding the synthesis of surface glycoproteins - hemagglutinin (NA) and neuraminidase (NA), M1 and M2 matrix polypeptides, NS1 and NS2 nonstructural proteins, nucleocapsid (NP), polymerases (PB1, PB2, PA) and F2 protein . 
The most variable structural components of the virion are surface antigens - HA and NA, which play an important role in the initial stages of cell infection, since it is against them that protective antibodies are formed in the host organism.

The classification of influenza A viruses is based on antigenic differences of HA and NA, detected in serological reactions using specific sera, or in BLAST analysis of sequenced gene sequences [3]. The subtype of all currently isolated influenza A viruses is determined by a combination of known subtypes HA and NA - H1N1, H3N2, H5N1, H7N7, and others. The most recently identified types of HA and NA are represented in H17N10 and H18N11 viruses isolated from bats in Central America [4]. Due to the lack of hemagglutinating and neuraminidase activity in these viruses, some authors propose to designate their surface glycoproteins as "HA-like" and "NA-like" ("HA-like" and "NA-like"), "HL17NL10" and "HL18NL11", respectively [5].Based on molecular phylogeny, all HAs are divided into two parts; Group 1 - H1, H2, H5, H6, H8, H9, H11, H12, H13, H16, H17 and H18; group 2 - H3, H4, H7, H10, H14 and H15 [4, 6].

The natural ecological niche of influenza A viruses is wild waterfowl, mainly of the orders Anseriformes (including ducks, geese and swans) and Charadriiformes (including gulls, terns, sandpipers, sandflies, etc.) in which identified the majority of known subtypes of the pathogen [7]. Of all the theoretically possible genetic diversity of influenza A viruses subtypes, formed by known species of HA and NA, at least 55 variants are isolated in wild avifauna [8]. Coinfection of birds with two viruses of different subtypes leads to reassortment of the HA and NA genes, which ultimately generates a variety of human and mammalian influenza [7]. The prevalence of infection in populations of synanthropic birds (e.g., passerine) is usually much lower than in aquatic avifauna; this suggests that they are secondary hosts and may play a role in the transport of viruses between poultry farms.

\section{Characterization of influenza A / H10 viruses}

The influenza subtype A/H10 virus (A/chicken/Germany/n/1949-H10N7) was isolated for the first time in 1949 from chickens in Germany [9]. Then virus A (H10N8) was isolated in 1965 from quail in Italy [10] and it was later found in wild birds in Australia, Sweden, North America (Canada and the USA) and Asia (China, Korea, Japan) [10, 11]. In southern Kazakhstan in 1978-1981 during virological examination of 1773 wild birds of 24 species of nine orders 42 isolates of influenza virus with antigenic formula A (H10N5) were allocated [12]. In the People's Republic of China, A/H10 was identified in a sample of water from the lake Dongin in 2007 [13], in 2012 isolated from duck in Guangdonge [14] and from wild birds in Mongolia [10].

The original, wild-type A (H10N8) avian virus from Lake Dongin had low pathogenicity in chickens and reproduced in the lungs of mice during an asymptomatic infection. However, after two passages from lung to lung, it acquired the ability to cause a fatal disease in them [13]. Phylogenetic analysis of sequences from the NCBI database showed that A virus (H10N8), which had been isolated for a long time only from migratory birds, could spread from them to poultry in southern China. Like other HAs of avian influenza viruses subtype H10 is divided into the North American and more diverse Eurasian lines [15]. H. Wu et al. [16] isolated in live poultry markets in 20162017 seven H10 avian influenza viruses, H10N3 $(n=2), H 10 N 7(n=1)$, and H10N8 $(\mathrm{n}=4)$ from chickens in Zhejiang Province, Eastern China. Phylogenetic analysis indicated that Zhejiang H10 strains received gene segments from H10, H3, H7 viruses from birds in East Asia, have low pathogenicity in mice and can replicate in this species. Authors suggest these viruses have the ability to adapt to chicken or other poultry, and highlight the need of long-term surveillance.

At the same time, it should be noted that wild avifauna is not the only possible reservoir for the $\mathrm{H} 10$ influenza virus, in particular, it has been reported that feral dogs 
have been infected with avian H10N8 in live bird markets in China (Guangdong province) [17] and mink in Scandinavia [18].

Representatives of the H10 subtype were able to cause lethal diseases in mammals, so the A (H10N4) virus was isolated from minks that died from pneumonia during an outbreak in Sweden [18]. At the same time, aerosol infection of minks by A (H10N7) leads to slight lesion of lung [19]. Intranasal inoculation of A (H10N4) to minks causes interstitial pneumonia, although analysis did not reveal the presence of a characteristic polybasic amino acids in HA cleavage site [20]. It has been established that the NS1 protein of this virus strongly suppresses the expression of the interferon promoter, which suggests that high pathogenicity is induced by this polypeptide. Virus A (H10N5) is also found in pigs; in addition, recombinant $\mathrm{H} 10$ in $\mathrm{A}$ (H10N7), isolated from a shorebird, is mainly associated with ciliated and non-ciliated cells in ex vivo human trachea sections [21].

Another host of the influenza $\mathrm{A} / \mathrm{H} 10$ virus is common seals (Phoca vitulina). Influenza virus H10N7 was found to be involved in the mass death of seals in Denmark, Sweden, Germany and the Netherlands in 2014 [22]. The spread of influenza A virus among marine mammals seems to be due to the ecology of these animals and close contact with the avian reservoir of the pathogen.

R. Bodewes et al. [23] studied the etiological agents of an outbreak of influenza A (H10N7) among seals in 2014-2015 in Northern Europe, and conducted a spatiotemporal analysis of the accumulation of mutational changes in their structure. Analysis of the complete genomes of A/Seal/Sweden/SVA0546/2014, A/harbor seal/Germany/S1047_14_L/2014 and A/harbor seal/NL/PV14-221_TS/2015 according to the results of a BLAST search showed that all gene segments are most closely related to gene segments of influenza A viruses found in wild or domestic birds of Eurasia. A comparison of the amino acid sequences of various influenza A viruses (H10N7) with those of the Eurasian avian influenza A viruses available in the databases showed that A/Seal/Sweden/SVA0546/2014 contains amino acids in six positions that were absent in avian influenza viruses; they were in three positions in HA (351H, 379I and 398D), in two places in PB2 (17C and 453S) and in one site in PA (192H).

Analysis of mean pairwise identities on the level of nucleotide and deduced amino acid levels between the sequences of the complete genomes of A/Seal/Sweden/SVA0546/2014 (April 2014; "early"), A/harbor seal/Germany/S1047_14_L/2014 (October 2014; "medium") and A/harbor seal/NL/PV14-221_TS/2015 (January 2015; "late") revealed a higher pairwise similarity of sequences between the internal gene segments of these viruses than those of the HA and NA genes. The NS gene had the lowest pairwise identities of the internal segments of the genome, with average values of $99.5 \%$ at the level of nucleotides and $99.1 \%$ at the level of amino acids. The average pairwise identities between the HA genes of the analyzed viruses were $99.1 \%$ at the level of nucleotides and $98.2 \%$ at the level of amino acids. At the same time, paired identities between the NA genes of the viruses analyzed were $98.8 \%$ at the level of nucleotides and $98.7 \%$ at the level of amino acids. Additional analysis of paired identities of HA and NA at two levels showed that the relatively low paired identity of NA was caused mainly by the NA of the virus A/Seal/Sweden/SVA0546/2014; the average pair identity for other analyzed viruses was 99.5\% at both levels [23].

By comparing the complete amino acid sequences of A/Seal/Sweden/SVA0546/2014 (April 2014), A/harbor seal/Germany/S1047_14_L/2014 (October 2014) and A/harbor seal/NL/PV14221_TS/2015 (January 2015), 12 amino acid changes were observed in internal proteins between A/Seal/Sweden/SVA0546/2014 and two other strains. Five of them were present in both A/Harbor Seal/Germany/S1047_14_L/2014 and A/Harbor 
Seal/NL/PV14-221_TS/2015, and four were only in A/Harbor Seal/NL/PV14221_TS/2015. Comparison of these substitutions with sequences of Eurasian influenza A viruses from wild birds from the database showed that modification of PB1 752D was absent in wild bird viruses.

In NA A/harbor seal/NL/PV14-221_TS/2015 (January 2015), amino acids 247I and 436T were detected, which were not found either in the "early" or "medium" influenza A (H10N7) viruses of the seal or in the available sequences of influenza viruses of wild birds from Eurasia.

Over time, and in different geographical locations, the HA of the "early", "middle" and "late" sequences experienced a gradual accumulation of amino acid substitutions, ten of them (82K, 204Q, 220L, 236K, 238I, 379I, 381K, 398D, 482D, 508N) were not found in the available sequences of the Eurasian influenza A virus (H10N7). In addition, a number of amino acid changes were found only in a part of the HA viruses of influenza A (H10N7) studied.

Conducted by R. Bodewes et al. [23] phylogenetic analysis of the HA gene sequences of influenza A viruses (H10N7) of seals showed that the evolutionary changes accumulated during the development of the outbreak as the epidemic spread to the south along the western coast of Europe had a ladder-like appearance. Similar results were obtained with the inclusion of additional samples in which it was possible to determine only a partial sequence of the HA gene. In addition to this stepwise evolution, a series of sequences, mainly from Germany, formed a separate cluster that branched off from the main tree. Most amino acid changes were observed when comparing different "early" strains with each other and with the "middle" strain (A/harbor seal/Germany/S1047_14_L/2014), while the " middle" strain differed only in three positions of amino acids from the "late" virus (A/harbor seal/NL/PV14221_TS/2015). Thus, the authors were able to track the genetic changes of the avian influenza virus H10N7 shortly after introduction into the seal population. The results highlight the ability of the avian influenza A virus to quickly adapt to the mammalian host and cause an outbreak with significant morbidity and mortality.

The first human case of avian influenza A H10N8 was reported in December 2013 in China, in Jiangxi Province [24, 25]. A 73-year-old woman fell ill four days after visiting a live bird market, and died 13 days later. The virus isolate isolated from her was designated A/Jiangxi-Donghu/346/2013 (A/JX346). The second and third infections of H10N8 were registered in 2014 in China; all three patients had antibodies against the homologous virus. Clinical manifestations included severe pneumonia, accompanied by fever and fatigue [26, 27].

Another representative of the H10 subtype capable of infecting humans was the influenza A virus (H10N7), and there were reported cases of conjunctivitis caused by this pathogen in Egypt in 2004 and Australia in 2010 [28, 29].

T. Zhang et al. [30] according to genetic analysis, revealed that human A/JX346 had sequence identity of $>99 \%$ in each of the 8 genes tested with two H10N8 viruses isolated from healthy chickens on the live poultry market in Jiangxi Province (JXB15 and JX77). The results of phylogenetic analysis confirmed that the HA genes of JXB15 and JX77 belong to the Eurasian line, while the NA genes belonged to the North American lineage of the avian influenza virus. The nucleotide sequence differences of the JX346 HA genes with the similar genes of JXB15 and JX77 avian isolates resulted in only 5 amino acid substitutions: Met80Tyr, Asn116Asp, Thr188Ile, Lys415Met and Phe-536Val. At the same time, the NA amino acid sequences of all three isolates were $100 \%$ identical.

The phylogenetic trees of six internal genes (PB1, PB2, RA, M, NS1 and NS2) of viruses JXB15, JX77 and JX346 revealed their cluster affinity with H9N2 virus strains 
isolated from local birds in 2010 and 2011. Results indicate genetic reassortment between these viruses in poultry populations [30].

At the initial stage of infection HA of the influenza A virus binds to sialic acid as part of the receptor on the surface of the host cell. Sialic acid is the final sugar of $\mathrm{N}$ - and O-linked glycoproteins, which are present in most receptors in birds and mammals, which allows viruses to use this universal structure. There are many types of sialic acids, and the relative affinity of HA varies depending on its type, which is one of the factors of host specificity. The majority of influenza A viruses interact with receptors containing $\alpha-2,3$-linked sialic acid $(\alpha-2,3-\mathrm{SA})$ and found in the respiratory tract and gastrointestinal tract of birds [31]. In most humans, the upper respiratory tract receptors contain $\alpha-2,6-\mathrm{SA}$, with which pathogens adapted to humans form a stronger binds. A study of the type and prevalence of various conformations of sialic acid receptors showed that poultry of some species have receptors in the airways with both $\alpha-2,6-\mathrm{SA}$ and $\alpha-2,3-S A$ molecules. These include quails, turkeys and pheasants, which are often found on live bird markets, where avian influenza viruses can be transmitted to other species, including humans [32].

K. To et al. [25] studied the amino acid sequences of HA of avian influenza A (H10N8) viruses in the NCBI database for the detection of known markers of mammalian adaptation and virulence. HA molecules of some strains contained A135T (94.4\%, 17/18) and S138A $(73 \%, 13 / 18)$, which promote adaptation [33]. They all carried in protein M1 N30D and T215A, and 95\% (19/20) had a replacement for P42S in protein NS1, which is associated with increased virulence in mice $[34,35]$. In $10.5 \%$ (2/19) of viruses a very important replacement E627K, associated with the transmission of the pathogen between mammals was found [36], and which is more common in human influenza viruses A (H5N1) and A (H7N9) [37, 38]. In influenza viruses of birds adapted to poultry, and also in the composition of human viruses A (H5N1) and A (H7N9), characteristic deletions of the stalk part of NA were detected [39, 40, 41], missing in NA composition of the studied poultry H10N8 strains.

Unlike, as a rule, highly pathogenic $\mathrm{H} 7$ and $\mathrm{H} 5$ viruses, representatives of the $\mathrm{H} 10$ subtype have different virulence in chickens [42, 43]. In addition, some highly pathogenic influenza $\mathrm{A} / \mathrm{H} 10$ viruses do not contain a multibasic amino acid cleavage site in the HA, which serves as a marker for this property in birds [43, 44]. The findings suggest that clinical cases of influenza A (H10N8) in humans, as was the case with H7N9, could have resulted from asymptomatic outbreaks of H10N8 in poultry.

S. Vachieri et al. [45] studied the specificity of cell binding to the H10N8 virus, and have shown sufficient HA avidity for receptors of human respiratory tract cells for infecting humans. On the basis of the crystal structure of the HA H10 complex with the receptor, the authors found a similarity of the H1N1 pandemic virus of 1918 and the H7 human viruses isolated from patients in 2013 [46, 47]. At the same time, other studies also demonstrated that the $\mathrm{H} 10 \mathrm{~N} 8$ virus retains a strong preference for binding to receptors on avian mucous cells, and in this regard arginine in position 137 is important $[48,49,50]$. The combination of these two characteristics suggests that the influenza $\mathrm{A}$ (H10N8) viruses have a large epidemic significance in the event they acquire mutations that contribute to human-to-human transmission and possibly become pandemic. This circumstance demonstrates the importance of epidemiological control of the circulation of this infectious agent in populations of mammals, birds and among the population.

\section{CONCLUSION}

The accumulated information about the influenza $\mathrm{A} / \mathrm{H} 10$ virus indicates its active involvement in the natural evolution of influenza infection agents and genetic 
information exchange processes, which indicates the need for a detailed and comprehensive study of this pathogen.

\section{Acknowledgement}

This work was supported by the Ministry of Education and Science of the Republic of Kazakhstan (grant No. AP05132431).

\section{REFERENCES}

1 Jones K.E., Patel N.G., Levy M.A., Storeygard A., Balk D., Gittleman J.L., Daszak P. Global trends in emerging infectious diseases. Nature, 2008, vol. 451, pp. 990-993.

2 Всемирная организация здравоохранение [Электронный ресурс]. - Режим доступа: https://www.who.int/ru/news-room/detail, свободный.

3 Webster R., Govorkova E. Continuing challenges in influenza. Ann. N.Y. Acad. Sci., 2014, vol. 1323, pp. 115-139.

$4 \mathrm{Wu}$ Y., Tefsen B., Shi Y., Gao G. Bat-derived influenza-like viruses H17N10 and H18N11. Trends Microbiol., 2014, vol. 22, pp. 183-191.

$5 \mathrm{Ma}$ W., García-Sastre A., Schwemmle M. Expected and unexpected features of the newly discovered bat influenza A-like viruses. PLoS Pathog., 2015, vol. 11(6), e1004819. - Doi:10.1371/journal.ppat.1004819.

6 Russell R.J., Kerry P.S., Stevens D.J., Steinhauer D.A., Martin S.R., Gamblin S.J., Skehel J.J. Structure of influenza hemagglutinin in complex with an inhibitor of membrane fusion. Proc Natl Acad. Sci. Nov., 2008, vol. 105(46), pp. 17736-41.

7 Olsen B., Munster V.J., Wallensten A., Waldenström J., Osterhaus A.D., Fouchier R.A. Global patterns of influenza A virus in wild birds. Science, 2006, vol. 312, pp. 384-388.

8 Fouchier R.A., Munster V., Wallensten A., Bestebroer T.M., Herfst S., Smith D., Rimmelzwaan G.F., Olsen B., Osterhaus A.D., Characterization of a novel influenza A virus hemagglutinin subtype (H16) obtained from black-headed gulls. J Virol., 2005, vol. 79 , pp. 2814-2822.

9 Diseases of Poultry / D.E. Swayne, D.A. Halvorson, Y.M. Saif, H.J. Barnes, J.R. Glisson, A.M. Fadly, L.R. McDougald, D.E. Swayne. Io.: Diseases of poultry, 2003, $1409 \mathrm{p}$.

10 NCBI Influenza virus resource. Available at [Электронный ресурс]. Режим доступа: http://www.ncbi. nlm.nih.gov/genomes/FLU/Database/nph-select.cgi go Zdatabase, свободный.

11 Manzoor R., Sakoda Y., Mweene A., Tsuda Y., Kishida N., Bai G.R., Kameyama K., Isoda N., Soda K., Naito M., Kida H. Phylogenic analysis of the M genes of influenza viruses isolated from free-flying water birds from their Northern Territory to Hokkaido. Virus Genes, 2008, vol. 37(2), pp. 144-52.

12 Sayatov M.H. Ekologiya i immunologiya VGA(N1N1), cirkuliruyushchih sredi dikih ptic i naseleniya Kazahskoj SSR. Avtoref. diss. dokt. biol. nauk., 1986, pp. 45. (In Russian).

13 Zhang H., Xu B., Chen Q., Chen J., Chen Z. Characterization of an H10N8 influenza virus isolated from Dongting lake wetland. Virol J., 2011, vol. 8, pp. 42.

14 Jiao P., Cao L., Yuan R., Wei L., Song Y., Shen D., Gong L., Luo K., Ren T., Liao M. Complete genome sequence of an H10N8 avian influenza virus isolated from a live bird market in Southern China. J Virol., 2012, vol. 86(14), pp. 7716.

15 Liu S., Ji K., Chen J., Tai D., Jiang W., Hou G., Li J., Huang B. Panorama phylogenetic diversity and distribution of type A influenza virus. PLoS ONE, 2009, vol. 4. - Doi: 10.1371/journal.pone.0005022. 
$16 \mathrm{Wu}$ H., Yang F., Liu F., Xiuming Peng., Bin Chen., Linfang Cheng., Xiangyun Lu., Hangping Yao., Nanping Wu. Molecular characterization of H10 subtype avian influenza viruses isolated from poultry in Eastern China. Arch Virol., 2019, vol. 164, pp. 159.

17 Su S., Qi W., Zhou P., Xiao C., Yan Z., Cui J., Ji K., Zhang G., Gray G.C., Liao M., Li S. First evidence of H10N8 avian influenza virus infections among feral dogs in live poultry markets in Guangdong province. Clin. Infect., 2014, vol. 59, pp. 748-750.

18 Klingeborn B., Englund L., Rott R., Juntti N., Rockborn G. An avian influenza A virus killing a mammalian species - the mink, Brief report. Arch Virol., 1985, vol. 86(34), pp. 347-51.

19 Englund L. Studies on influenza viruses H10N4 and H10N7 of avian origin in mink. Vet Microbiol., 2000, vol. 74(1-2), pp. 101-7.

20 Zohari S., Metreveli G., Kiss I., Belak S., Berg M. Full genome comparison and characterization of avian $\mathrm{H} 10$ viruses with different pathogenicity in mink (Mustela vison) reveals genetic and functional differences in the non-structural gene. Virol J., 2010, vol. 7, pp. 145.

21 Shelton H., Ayora-Talavera G., Ren J., Loureiro S., Pickles R.J., Barclay W.S., Jones I.M. Receptor binding profiles of avian influenza virus hemagglutinin subtypes on human cells as a predictor of pandemic potential. J Virol., 2011, vol. 85(4), pp. 187580.

22 Zohari S., Neimanis A., Harkonen T., Moraeus C., Valarcher J.F., Avian influenza A (H10N7) virus involvement in mass mortality of harbour seals (Phoca vitulina) in Sweden. Eurosurveillance, 2014, vol. 19(46), pp. 2-7.

23 Bodewes R., Zohari S., Krog J.S., Hall M.D., Harder T.C., Bestebroer T.M., van de Bildt MWG., Spronken M.I., Larsen L.E., Siebert U., Wohlsein P., Puff C., Seehusen F., Baumgärtner W., Härkönen T., Smits S.L., Herfst S., Osterhaus ADME., Fouchier RAM., Koopmans M.P., Kuiken T. Spatiotemporal Analysis of the Genetic Diversity of Seal Influenza A(H10N7) Virus, Northwestern Europe. J Virology, 2016, vol. 90, pp. 9.

24 Parry J. H10N8 avian flu virus claims its first known human casualty. $6^{\text {th }}$ world conference on research integrity, Hong Kong, 2014, vol. 348, pp. 1360.

25 To K.K., Tsang A.K., Chan J.F., Cheng V.C., Chen H., Chen H., Yuen K.Y., Emergence in China of human disease due to avian influenza $\mathrm{A}(\mathrm{H} 10 \mathrm{~N} 8)$ - cause for concern. J Infect., 2014, vol. 68 (3, pp. 205-15.

26 World Health Organization. Avian influenza A (H10N8). [Электронный ресурс]. Режим доступа:wpro.who.int. w.wpro.who.int/china/mediacentre/factsheets/h10n8/en, свободный.

27 Qi W., Su S., Xiao C., Zhou P., Li H., Ke C., Gray G.C., Zhang G., Liao M. Antibodies against H10N8 avian influenza virus among animal workers in Guangdong Province before November 30, 2014, when the first human H10N8 case was recognized. BMC Med., 2013, vol. 12, pp. 205.

28 Arzey G.G., Kirkland P.D., Arzey K.E., Frost M., Maywood P., Conaty S., Hurt A.C., Deng Y.M., Iannello P., Barr I., Dwyer D.E., Ratnamohan M., McPhie K., Selleck P. Influenza virus A (H10N7) in chickens and poultry abattoir workers, Australia. Emerg Infect Dis., 2012, vol. 18(5), pp. 814-6.

29 Pan American Health Organization. Avian influenza virus A (H10N7) circulating among humans in Egypt // Available at: http://www1.paho.org/English/AD/DPC/CD/eid-eer-07-may- 2004.htm.

30 Zhang T., Bi Y., Tian H., Li X., Liu D., Wu Y., Jin T., Wang Y., Chen Q., Chen Z., Chang J., Gao G.F., Xu B. Human infection with influenza virus A(H10N8) from live poultry markets. Emerg Infect Dis., 2014, vol. 20, pp. 2076-2079. 
31 Squires R.B., Noronha J.V., Garcia-Sastre A., Macken C., Baumgarth N., Suarez D.L., Pickett B.E., Zhang Y., Larsen C.N., Ramsey A., Zhou L., Zaremba S., Kumar S., Deitrich J., Klem E., Scheuermann R.H. Influenza research database: An integrated bioinformatics resource for influenza virus research. Influenza Other Respir. Viruses, 2012, vol. 6, pp. 404-416.

32 Wan H., Perez D.R. Amino acid 226 in the hemagglutinin of H9N2 influenza viruses determines cell tropism and teplication in human airway epithelial cells. J. Virol., 2007, vol. 81, pp. 5181-5191.

33 de Wit E., Munster V.J., van Riel D., Beyer W.E., Rimmelzwaan G.F., Kuiken T., Osterhaus A.D., Fouchier R.A. Molecular determinants of adaptation of highly pathogenic avian influenza H7N7 viruses to efficient replication in the human host. J. Virol., 2010, vol. 84(3), pp. 1597-606.

34 Fan S., Deng G., Song J., Tian G., Suo Y., Jiang Y., Guan Y., Bu Z., Kawaoka Y., Chen $\mathrm{H}$. Two amino acid residues in the matrix protein M1 contribute to the virulence difference of H5N1 avian influenza viruses in mic. Virology, 2009, vol. 384(1), pp. 2832.

35 Jiao P., Tian G., Li Y., Deng G., Jiang Y., Liu C., Liu W., Bu Z., Kawaoka Y., Chen H. A single amino - acid substitution in the NS1 protein changes the pathogenicity of H5N1 avian influenza viruses in mic. J Virol., 2008, vol. 82(3), pp. 1146-54.

36 Steel J., Lowen A.C., Mubareka S., Palese P. Transmission of influenza virus in a mammalian host is increased by PB2 amino acids 627K or 627E/701N. PLoS Pathog., vol. 5(1).

37 To K.K., Chan J.F., Chen H., Li L., Yuen K.Y. The emergence of influenza A H7N9 in human beings 16 years after influenza A H5N1: a tale of two cities. Lancet Infect Dis., 2013, vol. 13, pp.

38 Jonges M., Welkers M.R., Jeeninga R.E., Meijer A., Schneeberger P., Fouchier R.A., Jong M., Koopmans M. Emergence of the virulence-associated PB2 E627K substitution in a fatal human case of highly pathogenic avian influenza virus $A(H 7 N 7)$ infection determined by illumina ultra-deep sequencing. J. Virol., 2013, vol. 88(3), pp. 1694-702.

39 Croville G., Soubies S.M., Barbieri J., Klopp C., Mariette J., Bouchez O., CamusBouclainville C., Guérin J.L Field monitoring of avian influenza viruses: whole-genome sequencing and tracking of neuraminidase evolution using 454 pyrosequencing. J Clin Microbiol., 2012, vol. 50(9), pp. 2881-7.

40 Matrosovich M., Zhou N., Kawaoka Y., Webster R. The surface glycoproteins of H5 influenza viruses isolated from humans, chickens, and wild aquatic birds have distinguishable properties. J. Virol., 1999, vol. 73(2), pp. 1146-55.

41 Gao R., Cao B., Hu Y., Feng Z., Wang D., Hu W., Chen J., Jie Z., Qiu H., Xu K., Xu X., Lu H., Zhu W., Gao Z., Xiang N., Shen Y., He Z., Gu Y., Zhang Z., Yang Y., Zhao X., Zhou L., Li X., Zou S., Zhang Y., Li X., Yang L., Guo J., Dong J., Li Q., Dong L., Zhu Y., Bai T., Wang S., Hao P., Yang W., Zhang Y., Han J., Yu H., Li D., Gao G.F., Wu G., Wang Y., Yuan Z., Shu Y. Human infection with a novel avian-origin influenza A (H7N9) virus. N Engl J Med., 2013, vol. 16, pp. 1888-97.

42 Kim H.R., Lee Y.J., Oem J.K., Bae Y.C., Kang M.S., Kang H.M., Choi J.G., Park C.K., Kwon Y.K. (2012) Characterization of H10 subtype avian influenza viruses isolated from wild birds in South Korea. Vet Microbiol., 2012, vol. 161(1-2), pp. 222-8. 43 Wood G.W., Banks J., Strong I., Parsons G., Alexander D.J. An avian influenza virus of H10 subtype that is highly pathogenic for chickens, but lacks multiple basic amino acids at the haemagglutinin cleavage site. Avian Pathol., 1996, vol. 25(4). pp. 799-806. 
44 Wood G.W., McCauley J.W., Bashiruddin J.B., Alexander D.J. Deduced amino acid sequences at the haemagglutinin cleavage site of avian influenza A viruses of $\mathrm{H} 5$ and H7 subtypes. Arch Virol., 1993, vol. 130(1-2), pp. 209-17.

45 Vachieri G., Xiong X., Collins P., Walker Ph., Martin S., Haire L., Zhang Yi., McCauley J., Gamblin S., Skehel J. Receptor binding by H10 influenza viruses. Nature, 2014, vol. 511, pp. 475-477.

46 Gamblin S., Haire L.F., Russell R.J., Stevens D.J., Xiao B., Ha Y., Vasisht N., Steinhauer D.A., Daniels R.S., Elliot A., Wiley D.C., Skehel J. The structure and receptor binding properties of the 1918 influenza hemagglutinin. Science, 2004, vol. 303, pp. $1838-1842$.

47 Xiong X., Martin S.R., Haire L.F., Wharton S.A., Daniels R.S., Bennett M.S., McCauley J.W., Collins P.J., Walker P.A., Skehel J.J., Gamblin S.J. Receptor binding by an H7N9 influenza virus from humans. Nature, 2013, vol. 499, pp. 496-499.

48 Zhang H., de Vries R.P., Tzarum N., Zhu X., Yu W., McBride R., Paulson J.C., Wilson I.A. A human-infecting H10N8 influenza virus retains a strong preference for avian-type receptors. Cell Host Microbe, 2015, vol. 17, pp. 377-384.

49 Yang H., Carney P.J., Chang J.C., Villanueva J.M., Stevens J. Structure and receptor binding preferences of recombinant hemagglutinins from avian and human H6 and H10 influenza A virus subtypes. J Virol., 2015. vol. 89, pp. 4612-4623.

50 Ramos I., Mansour M., Wohlbold T.J., Ermler M.E., Hirsh A., Runstadler J.A., Fernandez-Sesma A., Krammer F. Hemagglutinin receptor binding of a human isolate of influenza A (H10N8) virus. Emerg Infect Dis., 2015, vol. 21, pp. 1197-1201.

\section{ҚҰСТАРДЫН, СУТҚОРЕКТІ ЖАНУАРЛАРДЫН ЖӘНЕ АДАМДАРДЫН ТҰМАУ А/10 ВИРУСЫ}

Жуматов К., Кыдырманов А.И.

Микробиология және вирусология вылыми-өндірістік орталывы 105, Богенбай батыр к., Алматы қ.., 050010, Қазақ̧стан

Lizaveta4ka@list.ru

\section{ТУЙІН}

Қайта пайда болған инфекциялық аурулардың саны ұдайы өсуде, сондықтан олар жабайы табиғатқа, үй жануарлары мен тұрғындардың денсаулығына қауіп төндіреді. Адамдардың соңғы алты онжылдығында пайда болған 335 аса ауруының ішінде, АҚШ-тың (СDC) мен ДДҰ ауруларды алдын алу және қадағалау Орталығының соңғы бағалауы бойынша тұмау (жылына 650 000 жуық өлім) ең кең таралған инфекциялардың бірі саналады. Әр жылғы маусымдық А тұмауына қосымша, оның жаңа, пандемиялық жұғымталдығы жоғары нұсқасының пайда болуы аса қауіп төндіреді.

Шолымдық мақалада тұмау қоздырғыштарының заманауи классификациясы, бөліну көздерімен кұрылымдық ерекшеліктері сипатталған. Шығу тегі әр-түрлі А/H10 тұмау вирусының құрылымы, экологиясы, филогенезімен патогендігі жөніндегі әр-түрлі сұрақтарға бағытталған соңғы әдеби мәліметтер талқыланған. Тұмау А/H10 вирусы 
үшін мүмкін болатын резервуар ретінде жалғыз жабайы орнитофауна саналмайды. Құстың H10N8 Қытайдың құс базарында қаңғыбас иттерді зақымдауының, Скандинавияда құндыздарды, 2014 ж., H10N7 вирусы Дания, Швеция, Германия және Нидерланд елдерінде итбалықтардың жаппай өлуінің себебі болды. Алғашқы үш жағдай, A/H10N8 құс тұмауымен адамның зақымдануы 2013-2014 жж., Қытайдың Цзянси аймағында тіркеліп, біреуі өліммен аяқталды. Клиникалық көріністері пневмонияның ауыр түрімен, қызба және қалжыраумен жалғасты. Жабайы орнитофаунада, сүтқоректі жануарлар популяциясы мен тұрғындар арасында айналымда жүрген А/Н10 эволюциялық өзгергіштігі жөнінде деректер келтіріледі. Тұмау қоздырушыларының табиғи эволюциясы және генетикалық ақпаратпен алмасуға тұмау А/H10 вирусының белсенді қатысуына қорытынды жасалады. Тұмау А (H10N8) вирусының құс популяциясында, сүтқоректі жануарлармен тұрғындар арасындағы айналымын қадағалау қажеттілігі мен оның пандемия қоздырушысы ретінде ықтимал эпидемиологиялық қауіп-қатері баса айтылады.

Түйінді сөздер: тұмау вирусы А, кіші түрі а/Н10, құс, геном, өзгергіштік, филогенез.

\section{ВИРУСЫ ГРИППА А/Н10 ДИКИХ ПТИЦ, МЛЕКОПИТАЮЩИХ ЖИВОТНЫХ И ЧЕЛОВЕКА}

Жуматов К., Кыдырманов А.И.

Научно-производственный иентр микробиологии и вирусологии ул. Богенбай батыра, 105, г. Алматы, 050010, Казахстан

Lizaveta4ka@list.ru

\section{АБСТРАКТ}

Количество вновь возникающих инфекционных заболеваний в мире растет, и они представляют собой серьезную угрозу для дикой природы, домашних животных и здоровья населения. Из более чем 335 заболеваний человека, появившихся за последние шесть десятилетий, грипп является одной из наиболее распространенных инфекций, вызывающих, согласно новым оценкам Центра по контролю и профилактике заболеваний (CDC) США и ВОЗ, до 650000 смертей в год. В дополнение к ежегодному сезонному гриппу A, еще большую опасность представляет появление его нового, пандемического высоковирулентного варианта, против которого практически отсутствует иммунитет. В обзорной статье описываются структурные особенности, источники выделения и современная классификация возбудителей гриппа. Обобщены последние данные литературы по различным вопросам строения, экологии, филогенеза и патогенности вирусов гриппа А/Н10 различного видового происхождения. Отмечается, что дикая орнитофауна не единственный возможный резервуар для вируса гриппа Н10, птичий H10N8 заразил бродячих собак на рынках живой птицы в Китае, норок в Скандинавии, вирус H10N7 стал причиной массовой гибели тюленей в Дании, Швеции, Германии и Нидерландах в 2014 г. Первые три случая заболевания человека птичьим гриппом А H10N8 зарегистрированы в 2013-2014 гг. в Китае, в провинции Цзянси, один из которых закончился смертью. Клинические проявления включали тяжелую 
пневмонию, сопровождающуюся лихорадкой и усталостью. Приводятся сведения об эволюционной изменчивости вирусов А/Н10 циркулирующих в дикой орнитофауне, популяциях млекопитающих животных и среди населения. Делается вывод об активной вовлеченности вируса гриппа А/H10 в естественную эволюцию возбудителей гриппозной инфекции и процессы обмена генетической информацией. Подчеркивается потенциальная эпидемиологическая опасность вируса гриппа А (H10N8) как возможного возбудителя пандемии, и необходимость контроля его циркуляции в популяциях птиц, млекопитающих животных и среди населения.

Ключевые слова: вирус гриппа А, подтип А/Н10, птица, геном, изменчивость, филогенез. 